\title{
Strengthen the development of rural human resources in view of promoting the building of a new socialist countryside
}

\author{
The first author: Chen Lishuang \\ School of Management, University of Jinan \\ Jinan, China \\ e-mail: lishuangchen88@163.com
}

\author{
Corresponding author: Qiao Juling* \\ School of Management, University of Jinan \\ Jinan, China \\ *e-mail: sm_qiaojl@ujn.edu.cn
}

\begin{abstract}
Under the guidance of the concept of scientific development, great changes took place in rural areas. The degree of modernization is increasing. China is a large agricultural country. Farmers in our country at this stage still account for an important part. The development of human resource in rural areas is one of the key to the development of productive forces, but also it is the way to make the country powerful and make the people wealthy. Aiming at the current Situation and existing problems of Chinese rural human resources, this article will discuss the urgency and necessity of the development of human resources in rural areas in the new rural construction, expecting to promote the building of a new socialist countryside.
\end{abstract}

Keywords-Chinese rural areas, Development of rural human resources, The urgency and necessity

\section{INTRODUCTION}

Since the reform and opening up, the construction of a new socialist countryside in China is in full swing in rural areas on the earth. Great changes are happening in rural areas. But we should also be clear to realize that there are still some factors restricting the speed of the construction of a new rural socialism. One of the most critical factors is the rural human resources. Therefore, to strengthen the construction of socialist new countryside, we must develop the rural human resources vigorously. Since the reform and opening up, the construction of a new socialist countryside in China is in full swing in rural areas on the earth. Great changes are happening in rural areas. But we should also be clear to realize that there are still some factors restricting the speed of the construction of a new rural socialism. One of the most critical factors is the rural human resources. Therefore, to strengthen the construction of socialist new countryside, we must develop the rural human resources vigorously.

\section{The Current Situation AND EXISTING Problems of CHINESE RuRAL HuMAN RESOURCES}

Since the sixteenth national congress of the communist party of China, The Central Committee of CPC taking $\mathrm{Hu}$ Jintao as General Secretary has led 1.3 billion Chinese People, through unusual scientific development road. Under the guidance of Comrade $\mathrm{Hu}$ Jintao who put forward the concept of scientific development, great changes took place in the rural areas of China and the degree of modernization is increasing.
But we should recognize that the farmers in our country at this stage still account for an important part. Especially in the face of the objective reality that the rural, agriculture and peasant had took place profound changes and the new situation and new tasks of the industrialization, informatization, urbanization and internationalization's further development, constructing a harmonious society of socialism will focus on farmers and countryside. It can be said that it is impossible without harmonious farmers and rural areas to the whole harmonious society. The construction of a new socialist countryside is a fundamental problem concerning the country overall situation all the time.

A. The current situation of China's rural human resources

China is a large agricultural country. The rural population still accounts for the majority, which is an extremely valuable advantage resource to the development of China's agriculture. However, China's rural labor force's cultural level and the scientific and technological level are both low. The present situation of China's rural human resources is mainly reflected in the following aspects:

First, the number of rural human resource is big, but the quality is low. More than $90 \%$ of the illiteracy and semi-literate concentrate in the rural areas. The proportion of agricultural science and technology personnel is very small. According to the data released by the Chinese agricultural census office. The population of China's rural people is 65,6560000, of which 561480000 practitioners, illiterates and semi-illiterates accounts for $14.01 \%$, primary school education accounted for $42.15 \%$, junior high school education accounts for $38.04 \%$, high school education accounts for $5.07 \%$, technical secondary education accounts for $0.57 \%$, junior college or above degree education accounts for $0.16 \%$.

TABLE I. ThE PRACTITIONERS In ChinA's Rural AREAS

\begin{tabular}{|c|c|c|}
\hline degree of education & number of people & proportion \\
\hline Illiterate or semi-illiterate & 78660000 & $14.01 \%$ \\
\hline Primary school & 236660000 & $42.15 \%$ \\
\hline junior middle school & 213590000 & $38.04 \%$ \\
\hline Senior middle school & 28470000 & $5.07 \%$ \\
\hline technical secondary school & 3200000 & $0.57 \%$ \\
\hline junior college or above & 900000 & $0.16 \%$ \\
\hline
\end{tabular}

2012 China Statistical Yearbook

Second, rural human resources are imbalance, causing the waste of human resources. China's rural human resources is very rich, but serious imbalance, forming a strong contrast 
to the rich, The inefficient use and even idle of labor in general and the extreme lack of high-quality labor formed a strong contrast. The idle and serious waste of human resources emerged.

Third, the rural population is mostly concentrated in the first industry, namely farming mainly, So that rural human resources structure is irrational.

\section{B. The problem of the development of China's rural human resources}

More than three decades of reform and opening up, especially over the past decade, the development of China's rural human resources has made great progress. But along with the continued development of the reform, the rapid development of the market economy, especially in the era of the knowledge economy, The development of human resources in rural areas in China is relatively backward, which has been far from being able to meet the requirement of the present situation. Mainly reflected in the following aspects:

On the one hand, in the era of the knowledge economy and in the time of building a new socialist countryside, rural human resources have become the first resource for economic development, but this has not been fully recognized and valued. We do not pay enough attention to the development of human resources in rural areas, and we have ignored the importance of improving the comprehensive quality of the farmers fundamentally. The development of the rural human resources is still in the lower level. Influenced by the Chinese traditional ideas, the majority of farmers believe that education is to enter the higher school. Cultivating their children to attend university is to make the children go to the city to work instead of staying in the countryside. Having a narrow concept of education, the farmers have trained a number of outstanding talents for the city. But the overall quality of farmers has seriously declined. There are fewer and fewer talents in the rural.

On the other hand, the investment of the rural education is not enough, and the implementation is not in place. For a long time, the supply of the rural education and the actual needs of the rural areas do not match. The development of the rural education dependent on government financial investment, and the lack of local government financial had restricted the development of rural education, thus forming the contrast of the great potential of human resources and the low actual development ability.

In addition, an effective system for protecting the development of the human resources in rural areas is lacking. In our country, because of the long-term impact of the urban-rural dual structure, a lot of capital, technology, talent gathered in the city, many systems in rural areas are missing. The absence of an effective education system in rural areas has caused the inequality of rural education and urban education. The lack of effective rural health care system makes the sick farmers fail to heal in time, resulting in a decline in physical quality. The lack of the flow system of the rural human resources hinders normal flow of human resources in rural areas. China's household registration system added a lot of social functions, having seriously hindered the rural human resources development smoothly.

\section{THE URGENCY AND NECESSITY OF THE}

\section{DEVELOPMENT OF THE RURAL HUMAN RESOURCES IN THE} CONSTRUCTION OF NEW COUNTRYSIDE

In the eighteenth national congress of the communist party of China, Comrade Hu Jintao proposed: "Strengthening social construction must take protecting and improving the livelihood of the people as the focus. Improving the people's material and cultural living standards is the fundamental purpose of the reform and opening up and socialist modernization construction ". The Central Committee of the communist party of China taking Hu Jintao as the leadership summarized the experience of China's rural reform and development since the founding of new China, especially since the reform and opening up. Starting from the actual situation of our country and learning from international experiences, they have carried out a comprehensive and in-depth thinking to solve the "Three Rural" problems. They put forward the strategic thought of "building a new socialist countryside ", pointing out the road of rural reform and development for us.

The building of a new socialist countryside needs a large number of "having culture, understanding technology and management" new farmers. Training new peasants is not only the most pressing demand for the new rural construction, but also the core content of the new rural construction. Therefore, in the process of the building of a new socialist countryside, developing the rural human resources fully and effectively which play a tremendous role in promoting the new rural construction, is one of the fundamental problems to be solved in the current construction of new countryside. It is not only very important but also very urgent to speed up the rural human resources development.

A. The development of human resources in rural areas is the objective need to realize the goal of building a new socialist countryside

On strengthening social construction, The CPC Central Committee suggests that we must make protecting and improving the livelihood of the people as the key point, improving the people's material and cultural life level. The construction of new socialist countryside needs "production development, well-off life, rural civilization, clean and tidy village, democratic management ", and only through strengthening the exploitation of rural human resources can we achieve these goals.

To build the new socialist countryside that is production development and well-off life, we must closely rely on the hundreds of millions of farmers. Only through training them to be high-quality new farmers that have knowledge and understand technology and business management, can we promote the agricultural modernization and the development of agricultural production. Therefore the farmers can also get rich live a well-off life truly.

To build the new countryside that is civilized, clean and tidy, we also must rely on hundreds of millions of farmers. And only through strengthening the exploitation of rural 
human resources, improving farmers' ideological and moral quality and improving the comprehensive quality of farmers, can we promote the construction of socialist spiritual civilization in the rural areas. It is impossible to build the new rural construction of democratic management without the majority of high-quality farmers' participation.

Only through improving farmers' political quality and creating democratic politics in rural areas, can we promote the construction of the socialist political civilization in rural areas.

Therefore, developing the rural human resources vigorously is the objective requirement for building a new socialist countryside.

\section{B. The development of human resources in rural areas is} an inevitable requirement for the development of modern agriculture

The Central Committee of the communist party of China makes the development of modern agriculture as the primary task of the construction of new countryside. We must equip agriculture with the modern material conditions, transform agriculture with modern science and technology, promote agriculture with modern industry system, promote the agriculture with modern management form, lead agriculture with modern development idea, and develop agriculture by training the new peasants.

That is to say, only through developing the rural human resources effectively, and making a group of high-quality workers and all kinds of special talents which are needed for the new rural construction, can we develop the practical modern agriculture. Improving farmers' comprehensive quality is the foundation of building a modern agriculture. We must develop the rural human resources to Improve farmers' quality. Therefore, the development of human resources in rural areas is an inevitable requirement for the development of modern agriculture.

\section{The development of rural human resources is the basic condition of improving farmers' material and cultural life level.}

The employment is the necessary condition to let farmers out of poverty become rich. The employment problems are not solved, other problems will be impossible. Developing rural human resource vigorously is to solve the employment problems of the farmers. In the time of the construction of socialist new countryside, the employment problems of the surplus labor force in the countryside should become the basic problem which all sectors of society focus on and work hard to solve.

Development of human resources in rural areas is an urgent requirement to realize modernization, an important basis to speed up the rural urbanization, the essential strategy to solve the problem of employment and increasing revenue, and the basic conditions of improving farmers' material and cultural life level.

\section{CONCLUSION}

Human resources are the basis resources of modern economic development. For a large agricultural nation, developing and making good use of the rich rural human resources is the practical needs to promote the optimization of the rural industrial structure and transform the mode of agricultural growth.

In the new situation of deepening of economic globalization, the challenge of the knowledge economy is becoming more and more serious. Chinese has to strengthen the development of the human resources in rural areas to promote the building of a new socialist countryside actively and promote the development of the entire national economy and building a moderately prosperous society. It is an objective demand to do some research on human resource development and utilization in rural region and it is a tough task facing us now. Strengthening the development of the human resources in rural areas will certainly have an important practical significance and far-reaching historical significance.

\section{ACKNOWLEDGMENT}

Chen Lishuang thanks every scholars related to this paper. This paper refers to numerous scholars' literature. It will be very diffecult without the help and inspiration of the literature.

Chen Lishuang thanks School of Management, University of Jinan and all the students and tearchers that offer helps in the process of writing this thesis.

With your help, this thesis can be successfully completed. Thank you very much!

\section{REFERENCES}

[1] Liu Lixia. The farmers' quality problems in the new rural construction [J]. Luoyang Technology College 2007 (4).

[2] Zhang Xiaoming. The study of the development of rural human resources in the building of a new socialist countryside [J] Agricultural Economics, 2006, (12).

[3] Wei Min. Situation and Countermeasures of Rural Human Resources Development [J]. Economist .2005 (9).

[4] Sun Qiaoli. The study of the development of rural human resources in the perspective of the construction of new countryside [J] Ludong University (Philosophy and Social Sciences),2008, (3).

[5] Chang Haiyan. The present situation and countermeasures of the development of China's rural human resources [J]. J, 2011, (6).

[6] Hu jintao. Hold high the great banner of socialism with Chinese characteristics to strive for new victories of capturing the comprehensive construction well-off society [N]. The People's Daily, 2007-10-25.

[7] Hu jintao. At the Fifth Plenary Session of the Sixteenth Central Committee of the Communist Party of China " The eleventh five years plan suggestion about the national economy and social development made by The central committee of the communist party ".2005-10.

[8] National Bureau of Statistics.2012 China Statistical Yearbook. Beijing: China Statistics Press.

[9] Li Shangtian.On the New Village Construction and Rural Human Resource Development.Jornal of Nanning vocational technical College,2008(4) 